\title{
Development of Liver and Pancreas
}

\author{
Mukaddes EŞREFOĞLU'1 \\ 'Department of Histology and Embryology, Bezmialem Vakıf University School of Medicine, İstanbul, Turkey \\ ${ }^{2}$ Department of Histology and Embryology, İnönü University School of Medicine, Malatya, Turkey
}

\begin{abstract}
The parenchyma of the liver and pancreas is derived from the endoderm, whereas the stroma is derived from the mesoderm. Both of them are derived from the endoderm of the foregut as the esophagus, stomach, and a part of duodenum. At the $3^{\text {rd }}-4^{\text {th }}$ of development, the liver, gallbladder and bile ducts become diverticulum hepaticum that is derived from the caudal portion of the foregut. There were inductive effects of septum transversum and cardiac mesoderm for the development of liver diverticulum. The pancreas arise from the endoderm of the foregut. The pancreas is derived from the fusion of the ventral and dorsal pancreas bulbs, which arise from the endoderm of the duodenum. The inductive effects of the notochord and dorsal aorta play a role in the development of the pancreas. In this manuscript, we attempted to review the morphological and functional development of the liver and pancreas with the aid of pictures obtained from various stages of prenatal and postnatal development in the organs of rats.
\end{abstract}

Keywords: Development, liver, prenatal, postnatal, pancreas

\section{Liver Development}

The parenchyma of the liver originates from the endoderm and its stroma originates from the mesoderm. The liver, gall bladder, and bile ducts begin to develop from the caudal part of the anterior intestine, "diverticulum hepaticum," at the middle of the $3^{\text {rd }}$ week and at the beginning of the $4^{\text {th }}$ week (1-3). It has been shown that the simple cuboidal endodermal epithelium transforms into a pseudostratified columnar epithelium to form the liver diverticulum in this developmental period, which corresponds to the intrauterine $8.5-9^{\text {th }}$ day in mice (4). It was observed that the basal lamina limiting the hepatic endoderm was destroyed and hepatoblasts started to migrate into the septum transversum mesenchyme on the intrauterine $9.0-9.5^{\text {th }}$ day $(4,5)$. For this event, of course, there is a need for various transcription factors and signals from the endothelial cells (6). This intrinsic hepatic potential of the anterior intestine may be attributed to FOXA2, GATA4-6, and HHEX transcription factors, which play crucial roles in the early organogenesis of this part of the intestinal tract (7, 8). As a matter of fact, it has been shown that FOXA1 and FOXA2 deletion inhibit the liver growth from the anterior intestine in the early period (9). In humans, the liver diverticulum was first observed on the $22^{\text {nd }}-24^{\text {th }}$ days after ovulation (10). While the liver and intrahepatic bile ducts develop from the anterior part of the liver diverticulum, the gall bladder and extrahepatic bile ducts develop from the posterior part (6).

The hepatic diverticulum grows into the septum transversum, which is a splanchnic mesodermal mass extending between the heart anlage and the mesentery (1-3). The septum transversum mesoderm is known to support the growth of the liver bud (11-14). Bone morphogenetic protein (BMP), which is expressed in the connective tissue of the septum transversum, plays a very important role in liver development. The liver bud does not develop in mice without BMP-4 (15). Endoderm cells are characterized by stimulating signals and genetic regulatory factors. The fibroblast growth factor (FGF) originating from the cardiac mesoderm and the BMPs originating from the septum transversum are very important for hepatic induction $(10,15,16)$. Indeed, studies carried out on zebrafish, chicks, and Xenopus have shown that both BMP and FGF signals are important for liver differentiation $(17,18)$. 
The larger cranial part of the diverticulum hepaticum is called as the "primordium hepaticum" $(1,19,20)$. It has been shown that Wnt13 expressed from the cardiogenic mesoderm in mice and the frizzled-related protein 5 , which acts as a Wnt inhibitor, regulate the development of liver primordium along with mutually stimulating and repressive effects (15). When the cardiac mesoderm is removed in mice or when the FGF or BMP signaling pathways are blocked, the liver does not develop $(7,21,22)$. Exogenously administered FGF 1 and 2 act as cardiac mesoderm and provide the albumin expression in the endoderm cultures of the anterior intestine (10). It is not known whether the proximity or the duration of the interaction between the endoderm of the anterior intestine and the cardiac mesoderm affects the dose of FGF. This event may partially be regulated by the HHEX homeobox genes that regulate the proliferation of endoderm of the anterior intestine and the activation of the epithelium with respect to the cardiac mesoderm that produces FGF during development (23). As a matter of fact, HHEX, which is initially expressed from the ventral foregut endoderm in mice, increases in the hepatic endoderm as of the $8.5^{\text {th }}$ day and continues to remain in the hepatocellular cell lines throughout the entire developmental period $(24,25)$. In the accompaniment of appropriate signals, the hepatic diverticulum is transformed into hepatoblasts organized as cell cords. Hepatoblasts express many genes specific to hepatocytes, but it is difficult to recognize them cytologically in this period. With the effect of Notch signals and other regulatory proteins, hepatoblasts are transformed into hepatocytes, bile ductules, and hepatic ducts (15). It has been shown that hepatoblasts and septum transversum mesenchyme express various matrix metalloproteinases (MMPs) on the embryonic $9.5^{\text {th }}$ day in mice. The inhibition of MMP activity in culture inhibits hepatoblast migration (5). The transformation of hepatoblasts into hepatocytes or biliary epithelial cells is also under the influence of a series of regulatory factors. This transformation has been shown to take place around the $13^{\text {th }}$ day in mice. While the genes of hepatocytes, bile duct epithelial cells, and fetal liver are expressed in hepatoblasts at the beginning of the transformation process, the genes of the type into which the cell will transform are expressed in the forthcoming stages. It has been demonstrated that the hepatoblasts contacting the portal vein transform into bile duct epithelial cells and those that do not contact the portal vein transform into hepatocytes in mice. On the $17^{\text {th }}$ day, it was observed that hepatocytes were arranged in rows as that in the adult liver and that the bile canaliculus existed among them (6). TGF $\beta$, Wnt, and Notch signals originating from the periportal mesenchyme stimulate the development of the bile duct epithelium (2628). HHEX, OC1, and OC2 hepatobiliary cell lines have been shown to separate from each other and stimulate the differentiation toward early bile duct epithelium in the 13$15^{\text {th }}$ day in mice. It is likely that OC1 and OC2 are effective by partially controlling the responses that hepatoblasts give to TGF $\beta$ signals (29).
The liver cell cords travel through the septum transversum and meet the vitelline and umbilical veins. These vessels that are lined with the endothelium and are between the cell cords form the anlages of liver sinusoids $(1-3,11,19,20)$. In the intrauterine $6-7^{\text {th }}$ week, hematopoietic precursor cells and large blood vessels are seen among smooth-shaped polygonal hepatocyte groups (30). Hematopoietic stem cells of the liver originate initially from the wall of the yolk sac, then from the aortic, gonadal, and mesonephric regions (15). Hepatocyte groups give place to cell lines in the intrauterine $7-8^{\text {th }}$ week. During the $9^{\text {th }}$ week, hemopoietic cell islands are explicit and intrahepatic vessels contract. Hemopoietic cells increase in the intrauterine $10^{\text {th }}$ week (30). It has been demonstrated in rats that in the intrauterine $10-15^{\text {th }}$ day, the liver bud grows rapidly and becomes well vascularized: thereafter, it turns into the most important blood-forming organ during fetal life after being filled with hematopoietic cells. The paracrine signals originating from hepatic enzymes as well as the genes originating from hepatoblasts have regulatory effects in this growth (6). Following the appearance of bloodforming findings in humans, hepatocytes around the portal area change and begin to form the bile ducts (30). On the intrauterine $26^{\text {th }}$ day, an endodermal thickening appears in the ventral wall of the duodenum at the base of the hepatic diverticulum, budding toward the ventral mesentery. This area called the cystic diverticulum will form the bile duct and cystic channel. The cells at the junction of the hepatic and cystic channels reproduce to form the main bile duct. The cystic channel, therefore, moves away from the duodenum. In fact, the bile duct and the cystic channel originate from different cell populations of the duodenum (15).

During embryonic and fetal development, hepatocytes proliferate mainly by the effect of an autocrine mechanism. After birth, this proliferation decreases with time. Factors such as endothelial growth factor and hepatocyte growth factor are required for the migration and proliferation of hepatocytes during this period (15). The liver cell cords are initially in the form of cell assemblies that anastomose with each other. They are then restricted by the mesenchyme in small cell groups that form the lobules. There are small veins of portal circulation around the lobules. V. centralis that drains into v. hepatica through the collector veins is formed in the middle of the lobules (20). While this typical structure of the liver is formed, the mesoderm of the septum transversum divides the liver into lobes and lobules by making the connective tissue parts of the organ (31). The development of the lobes is initially symmetric. As the development progresses, the growth of the right-lobe accelerates $(1,19,20)$. It becomes difficult for the left lobe to find empty space due to the developing stomach. Some epithelial cell cords that form here in the early stages of development may lose their connection with the main buds because of the development of the stomach. Therefore, atrophied bile ducts may be encountered in the mesohepaticum laterale. These are called "vasa aberrnatia" (20). 
Supportive stromal tissue of the liver develops from the septum transversum and from the splanchnic mesoderm around the stomach (15). The hematopoietic tissue of the liver and Kupffer cells also originate from the septum transversum mesenchyme $(1,2,7,11,19)$. In humans, primitive sinusoidlike structures are seen between the liver cell cords in the $5^{\text {th }}$ week of gestation. Hepatic sinusoids completely develop in the intrauterine $6-8^{\text {th }}$ week. During this period, cells similar to the Kupffer cells are observed between the hepatocyte cords (32). Kupffer cells, which are few in the early intrauterine period, increase during pregnancy and almost reach the levels of an adult in the neonatal period (33).

The rapidly growing liver covers most of the abdominal cavity between the $5^{\text {th }}$ and $10^{\text {th }}$ week. In the $9^{\text {th }}$ week, it constitutes approximately $10 \%$ of the total fetal weight $(1,2,11,19,20$, 31). This is related to the fact that the liver is a hemopoietic organ during fetal life. The amount of oxygenated blood that flows through the v. umbilicalis into the liver determines the developmental and functional segmentation of the liver. Liver development is very rapid in comparison to the other organs. At birth, it covers half of the abdominal cavity, on average (20). The first function of the liver is hematopoiesis, which continues in the $1^{\text {st }}$ and $5-7^{\text {th }}$ months in human beings (13). This function gradually decreases until the last two months of pregnancy and several hematopoietic cell islands remain at birth (19). Biliary formation by the liver cells begins in the $12^{\text {th }}$ week $(1,2,11,19,31)$. Liver development continues for 6-12 months after birth and the liver of a child aged 1 year reaches the function level of the liver in an adult.

Figure 1 summarizes the changes in the liver of a rat during prenatal and postnatal development.

\section{Pancreas Development}

The pancreas develops from the caudal part of the foregut, i.e., from the dorsal and ventral pancreatic buds originating from the duodenum $(2,3,11,19,20,31)$. The region where the pancreas develops in human beings is between the $3^{\text {rd }}$ and $9^{\text {th }}$ somites (34). It has been shown that the development of the dorsal pancreas bud from the foregut endoderm is affected by the adjacent notochord $(35,36)$, as well as the signals coming from the dorsal aorta and other vessels (37, 38). In human embryos, the dorsal foregut epithelium, which is a single line in the 4-12 somite period, was found to be close to the notochord (39). In mice and chicks, it has been shown that the dorsal aorta induces pancreatic development, particularly the insulin expression of the dorsal pancreatic endoderm (37). While the dorsal and ventral pancreas buds initially extend in opposite directions, the ventral pancreas bud rotates with the duodenum and settles under the dorsal pancreas bud $(1-3,11,19)$. Between the postcoital $26^{\text {th }}$ and $35^{\text {th }}$ day, ventral and dorsal pancreas buds exist separately in human beings (40). The unification of these buds occurs between the postcoital $37^{\text {th }}$ and $42^{\text {nd }}$ day in human beings (41). The ventral pancreatic bud forms the uncinate extension and the proximal lower part of the pancreatic head. When the pancreas buds fuse, the ducts also fuse with each other. The main pancreatic duct (Wirsung duct) consists of the entire duct of the ventral bud and the distal part of the duct of the dorsal bud. The proximal part of the dorsal bud duct remains as the accessory pancreatic duct (Santorini duct) $(19,20)$. The main pancreatic duct merges with the ductus choledochus and opens into the major papilla region of the duodenum (1, $3,11,19,20)$.

In humans and mice, it has been shown that pancreatic development occurs in successively similar periods, but there are differences between the two species in terms of time. The border of the pancreatic areas and the formation and growth of the pancreatic bud are similar within the ventral and dorsal foregut in both the species. Following these events, separate cell lines are seen to become different $(39,42)$.

The sonic hedgehog, homeobox gene Pdx1, and Notch signaling systems are effective in the development of the pancreas $(43,44)$. The expression of $\mathrm{Pdx} 1$ from the duodenum during development is important in determining where the pancreatic bud will develop (43). In chick embryos, it has been shown that the adjacent notochord allows the Pdx1 expression, thereby inducing the budding of the dorsal pancreas by deactivating the sonic hedgehog expression coming from the dorsal foregut epithelium (36). The similar deactivation of the sonic hedgehog expression was also found in the 4-12 somite period of human embryos. The hedgehog expression continues in the thicker pseudostratified epithelium of the ventromedial endoderm, which is adjacent to the lateral mesoderm (39). The fact that the inhibition of the hedgehog signals also leads to the ectopic appearance of the pancreatic structures in the organs such as the stomach and duodenum (45) indicates that this system also plays a role in determining the area in which the pancreas will develop. It has been shown that Notch signals stimulate exocrine cell differentiation, but suppress endocrine cell differentiation (46). Follistatin and FGF are also involved in the development of exocrine pancreatic progenitors (47).

Pancreatic parenchyma is formed by the creation of a tubular network of the endoderm of pancreatic buds. In the early fetal period, acini develop from the cell clusters at the ends of these tubules $(1,3,11,19,20)$. All the cell types in the pancreas (endocrine, exocrine, and ductal cells) originate from the same stem cells of the dorsal and ventral endodermal buds (48). In fact, ductal cells also originate from the same progenitor cells. On the $14^{\text {th }}$ day of rat development, cells that will form the acinar cell line from the multipotent progenitor cell pool are largely completed $(49,50)$. While these cells containing GATA4 are located in the end portions of the pancreatic bud, the cells containing GATA4 and SOX9 settle in the body of the pancreas (51). During the development of human beings, GATA4-positive nuclei were seen in the nuclei of some of the peripheral cells on the postcoital $45-47^{\text {th }}$ day. SOX9 was also found in the cells located in the periphery 

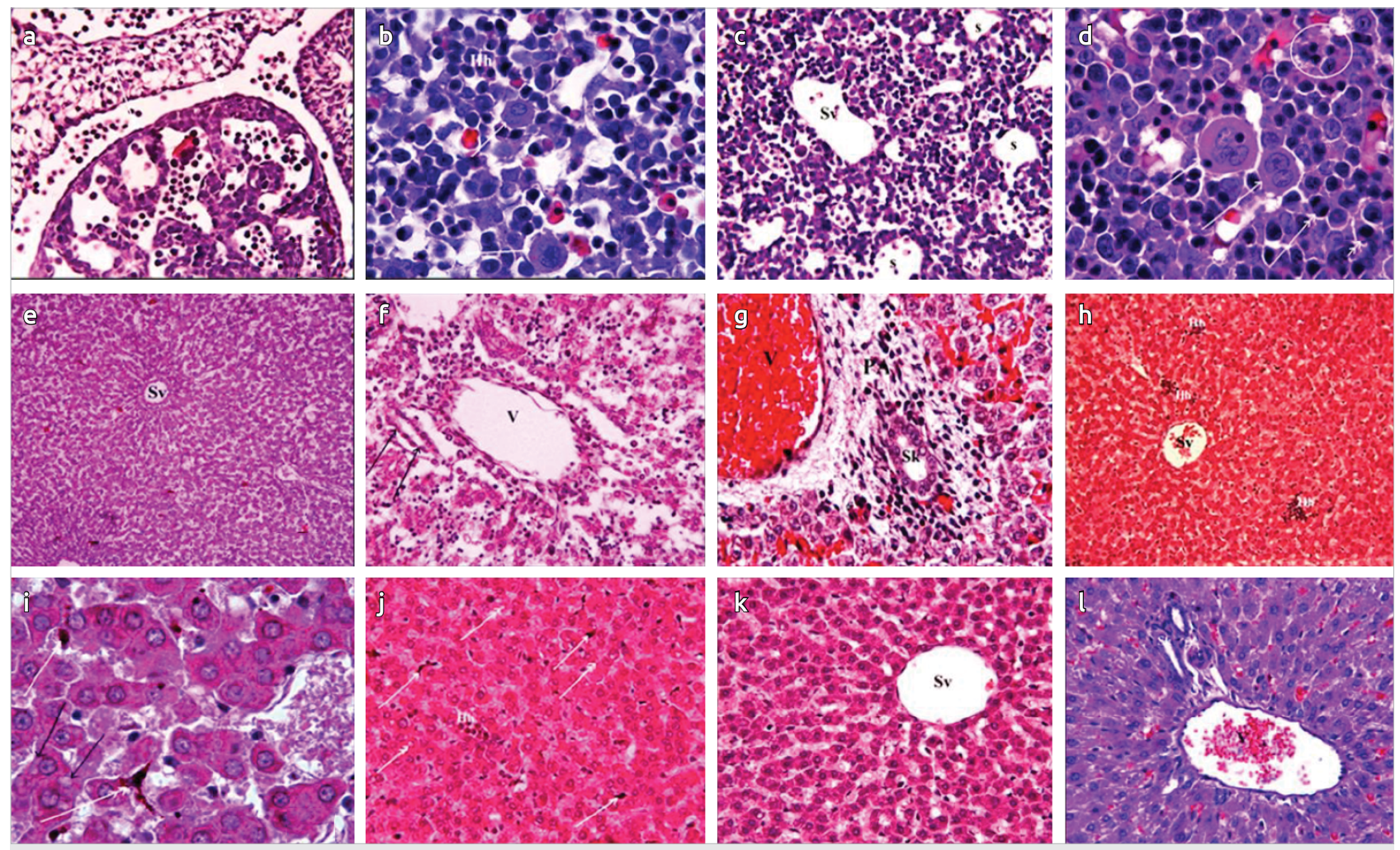

Figure 1. a-l. Changes in the liver in the prenatal period. (a) On the intrauterine (I.U.) $7^{\text {th }}$ day, hepatocyte precursors around irregular, wide spaces are observed. H-E; X 40. (b) On the I.U. $10^{\text {th }}$ day, intense hemopoietic cell (Hc) groups with hepatocyte precursors are observed. Out of these cells, megakaryocytes are easily recognized (arrows). H-E; X 100. (c) On the I.U. $14^{\text {th }}$ day, it is observed that lobulation is beginning to develop gradually. There are cell groups and local sinusoids around the central vein $(\mathrm{Cv})$ PAS; X 40. (d) On the I.U. $17^{\text {th }}$ day, hemopoesis continues. Lymphocyte cells (in the circle) and megakaryocytes (arrows) are marked. A lot of mitosis figures (two-headed arrows) are seen during this period. H-E; X 100. (e) On the I.U. $20^{\text {th }}$ day, it is observed that the lobular structure is clearer and hepatocyte cordons are radially sequenced from the central vein $(\mathrm{Cv})$ toward the periphery. H-E; X 10. (f) On the I.U. $20^{\text {th }}$ day, it is observed that the portal areas are beginning to appear and there is a portal vein $(\mathrm{V})$ surrounded with a little connective tissue and bile ducts (arrows) still lined with single-layered squamous epithelium. The changes in the liver in the postnatal period are observed. (g) On the postnatal $5^{\text {th }}$ day, it is observed that the portal area $(\mathrm{PA})$ is developed and the vein $(\mathrm{V})$, bile duct (Bd) lined with single-layered cuboidal epithelium, and artery (A) in the connective tissue are placed as that in adults. H-E; X 40. (h) On the postnatal $10^{\text {th }}$ day, a few small hemopoetic cells $(\mathrm{Hc})$ are seen in the parenchyma around the central vein $(\mathrm{Cv})$. H-E; X 20. (i) On the postnatal $10^{\text {th }}$ day, Kupffer cells (white arrows) including brown granules are seen on the wall of the sinusoid (probably, breakdown products of previously existing hemopoietic cells). Vacuoles are observed in the hepatocyte cytoplasm in this period (black arrows). H-E; X 100. (j) On the postnatal $15^{\text {th }}$ day, a rare hemopoetic cell Hc group is observed. Many Kupffer cells (arrows) on the wall of the sinusoid and vacuoles in the hepatocyte cytoplasm (two-headed arrows) are observed. H-E; X 40. (k) On the postnatal $20^{\text {th }}$ day, hepatocytes advancing from the central vein $(\mathrm{Cv})$ to the periphery are observed and it is recognized that a classical liver lobule appears as that in an adult. H-E; X 40. (I). Portal area is viewedobserved in a young adult. H-E; X 40 .

and in the body. After approximately 2.5 weeks, the SOX9 positivity disappeared in most of the GATA4-positive cells; it was thought that the positivity of both the factors was almost completely limited at the postcoital $14^{\text {th }}$ week and this suggested that the cells containing GATA4 were differentiated into the surrounding SOX9-positive centroacinar cells (39).

It is very difficult to work on human embryos due to ethical constraints. While the dorsal and ventral pancreas buds are observed separately from the postcoital $30^{\text {th }}$ to $33^{\text {rd }}$ day in human beings, pancreatic buds as well as the duodenum to which they are connected show nuclear PDX1 and GATA4 positivity. SOX9 gives strong positivity in pancreas buds and weak positivity in the duodenum. On the postcoital $35-37^{\text {th }}$ day, the pancreas moves away from the aorta, and PDX1, FOXA2, SOX9, and NKX6.1 positivity is seen in the nuclei of the epithelial cells (39).

The islets of Langerhans differentiate and diffuse into the organ in the third month of fetal life. The first cellular differentiation in the islets of Langerhans takes place in the $8-9^{\text {th }}$ week. The first cells formed by this differentiation are alpha and gamma 


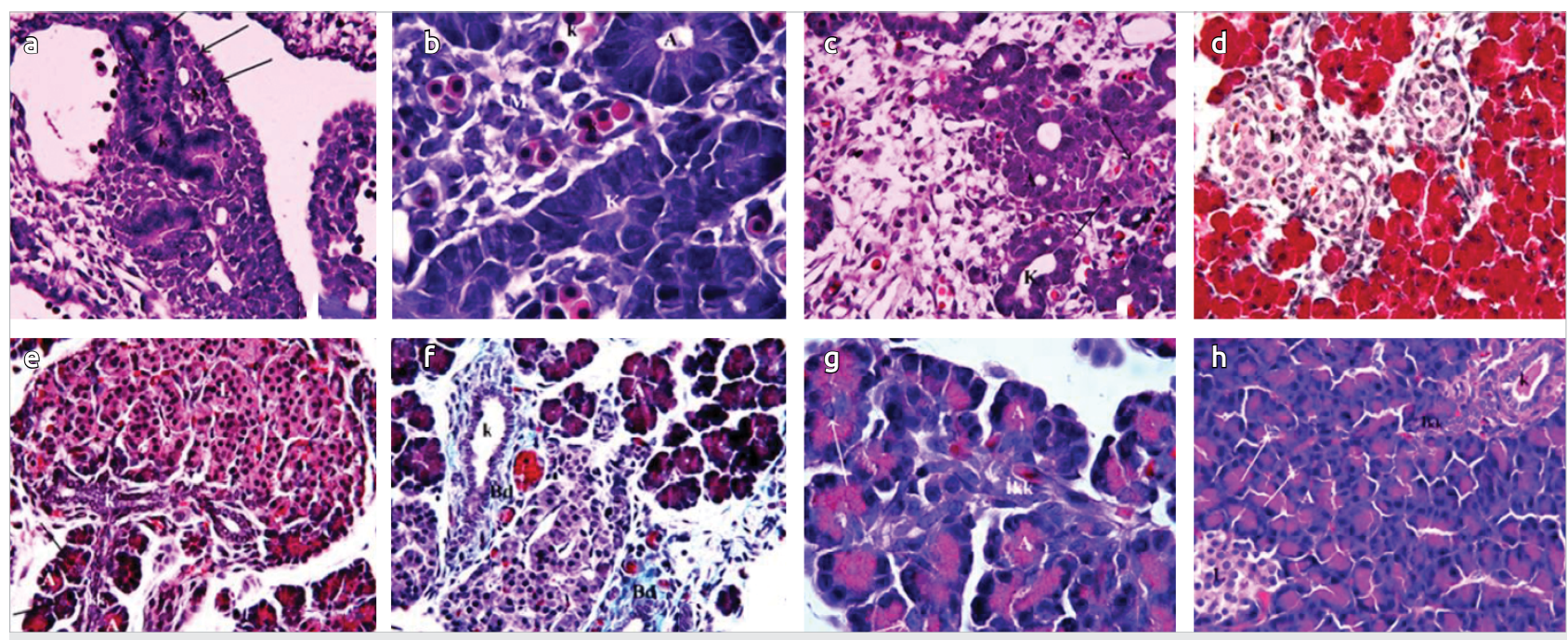

Figure 2. a-h. Changes in the pancreas in the prenatal period. (a) On the I.U. $10^{\text {th }}$ day, channels (C) lined with singlelayered epithelium in the mesenchymal tissue $(\mathrm{M})$ are observed. Acini and islets of Langerhans (L) are not seen in this period. H-E; X 40. (b) On the I.U. $14^{\text {th }}$ day, it is observed that channels (C) in the mesenchymal tissue (M) proliferate and form acini (A). H-E; X 100. (c) On the I.U. 17 th day, small Langerhans cell groups (L) are formed in the acini (A) and channels C. H-E; X 40. (d) On the I.U. $20^{\text {th }}$ day, it is observed that acini (A) are more widespread, cytoplasms are full of secretion material, and Langerhans islets (L) are wider. Masson's trichrome staining method; X 40 . The changes in the pancreas in the postnatal period. (e) On the postnatal $5^{\text {th }}$ day, intercalated channel (icc), excretion channel (c), acili (a), and Langerhans islet L are seen. H-E; X 40. (f) On the postnatal $10^{\text {th }}$ day, excretion channel (C), acini (A), and Langerhans islet $(\mathrm{L})$ are seen in the connective tissue. This appearance is very similar to the pancreas of an adult. Masson's trichrome staining method; X 40. (g) On the postnatal $10^{\text {th }}$ day, the connection between intercalated channelicc and acini (A) are observed and centroacinar cells are observed in the middle of acini (arrows). H-E; X 100. (h) Acini (A) and Langerhans islets (L) are observed in the pancreas of a young adult. PAS; X 20.

cells (12). In the intrauterine $14-16^{\text {th }}$ week, the cells that secrete insulin in the islets of Langerhans are located in the middle and the cells that secrete glucagon and somatostatin are located in the periphery. After the intrauterine $24^{\text {th }}$ week, this order is distorted and the islets begin to resemble adult islets (52). Fetal $\beta$-cell groups in mice appear on the postcoital $10^{\text {th }}$ day. Interestingly, there is an increase in the NEUROG3-positive cells and NEUROG3 expression in the late embryogenesis period, which is very close to the period in which fetal insulin appears in rats. A 34-fold increase in insulin that was compatible with a 3.6-fold increase in NEUROG3 transcripts was detected on the postcoital $8-8.5^{\text {th }}$ day, and a 102 -fold increase in insulin that was compatible with a 6.1-fold increase in the NEUROG3 transcripts was detected on the postcoital 9-10 ${ }^{\text {th }}$ day. In the same period, 140-fold and 648-fold increases in the insulinpositive cells were found in correlation with a 59- and 102fold increase in the NEUROG3-positive cells, respectively (39). In humans, insulin secretion begins at the $10^{\text {th }}$ week and secretion of glucagon begins at the $15^{\text {th }}$ week $(1,11,12)$. Insulin and glucagon could be detected in the $4-5^{\text {th }}$ month of the fetal circulation (12). Fetal insulin levels are independent of maternal insulin levels $(1,3,11,19,20)$. Total pancreatic insulin and glucagon contents also increase along with fetal growth $(2,3)$.

Figure 2 summarizes the changes in the pancreas of a rat during prenatal and postnatal development.
Peer-review: Externally peer-reviewed.

Author Contributions: Concept - M.E., E.T., A.Ç.; Design - M.E., E.T., A.Ç.; Supervision - M.E., E.T., A.Ç.; Funding - M.E.; Materials - M.E.; Data Collection and/or Processing - M.E.; Analysis and/or Interpretation - M.E.; Literature Review - M.E.; Writing - M.E.; Critical Review - M.E.

Conflict of Interest: No conflict of interest was declared by the authors.

Financial Disclosure: The authors declared that this study has received no financial support.

\section{References}

1. Moore KL, Persaud TVN. Klinik yönleri ile İnsan Embriyolojisi. (M. Yıldırım, İ. Okar, H. Dalçık, Çev.). 1. baskı, İstanbul: Nobel Matbaacılik; 2002.

2. Moore KL, Persaud TVN. Embriyoloji ve doğum defektlerinin temelleri. (S. Müftüoğlu, P. Atilla, F. Kaymaz, Çev.). 7. Baskı, İstanbul: Güneş Tip Kitabevleri; 2009.

3. Schoenwolf GC, Bleyl SB, Brauer PR, Francist-West PH. Larsen's Human Embryology. 4 th ed. Philadelphia: Churchill Livingstone; 2009.

4. Bort R, Signore M, Tremblay K, Barbera JP, Zaret KS. Hex homeobox gene controls the transition of the endoderm to a pseudostratified, cell emergent epithelium for liver bud development. Dev Biol 2006; 290: 44-56 [CrossRef]

5. Margagliotti S, Clotman F, Pierreux C.E, Lemoine P, Rousseau G. G, Henriet P, et al. Role of metalloproteinases at the onset of liver development. Dev Growth Differ 2008; 50: 331-8. [CrossRef]

6. Zorn AM. Liver development in StemBook. Cambridge: Harvard Stem cell Institute; 2008. 
7. Gualdi R, Bossard P, Zheng M, Hamada Y, Coleman JR, Zaret K.S. Hepatic specification of the gut endoderm in vitro: cell signaling and transcriptional control. Genes Dev 1996; 10: 1670-82. [CrossRef]

8. Bossard P, Zaret K.S. GATA transcription factors as potentiators of gut endoderm differentiation. Development 1998; 125: 4909-17.

9. Lee CS, Friedman JR, Fulmer JT, Kaestner KH. The initiation of liver development is dependent on Foxa transcription factors. Nature 2005; 435: 944-47. [CrossRef]

10. Jung J, Zheng M, Goldfarb M, Zaret KS. Initiation of mammalian liver development from endoderm by fibroblast growth factors. Science 1999; 284: 1998-2003. [CrossRef]

11. Sadler TW. Langman's Medikal Embryology. 6. ed., Philadelphia: Williams and Wilkins; 2006.

12. Carslon BM. Human embryology and developmental biology. 4th. ed. Philadelphia: Mosby Elsevier; 2009.

13. Houssaint E. Differentiation of the Mouse hepatic primordium. I. An analysis of tissue interactions in hepatocyte differentiation. Cell Differ 1980; 9: 269-79. [CrossRef]

14. Kung JW, Currie IS, Forbes SJ, Ross JA. Liver development, regeneration and carcinogenesis. J Biomed Biotechnol 2010. [CrossRef]

15. Larsen W. Development of the gastrointestinal tract. In: Sherman LS, Potter SS, Scott WJ, eds. Human Embryology, 3rd ed. Philadelphia: Churchill Livingstone; 2001: 235-64.

16. Rossi JM, Dunn NR, Hogan BLM, Zaret KS. Distinct mesodermal signals, including BMPs from the septum transversum mezenchyme are required in combination for hepatogenesis from the endoderm. Genes Dev 2001; 15: 1998-2009. [CrossRef]

17. Shin D, Shin CH, Tucker J, Ober EA, Rentzsch F, Poss KD, et al. Bmp and Fgf signaling are essential for liver specification in zebrafish. Development 2007; 134: 2041-50. [CrossRef]

18. Zhang W, Yatskievych TA, Baker RK, Antin PB. Regulation of Hex gene expression and initial stages of avian hepatogenesis by Bmp and Fgf signaling. Dev Biol 2004; 268: 312-26. [CrossRef]

19. Şeftalioğlu, A. Genel \& Özel İnsan Embriyolojisi. 3. baskı, Ankara: Tip \& Teknik Yayıncllık Ltd. Şti, 1998.

20. Kayalı H, Şatıroğlu G, Taşyürekli M. İnsan Embriyolojisi. 7. Baskı, İstanbul: Alfa Basım Yayım Dağıtım, 1992.

21. Calmont A, Wandzioch E, Tremblay K.D, Minowada G, Kaestner KH, Martin GR, et al. An FGF response pathway that mediates hepatic gene induction in embryonic endoderm cells. Dev Cell 2006; 11: 339-48 [CrossRef]

22. Rossi JM, Dunn NR, Hogan BL, Zaret KS. Distinct mesodermal signals, including BMPs from the septum transversum mesenchyme, are required in combination for hepatogenesis from the endoderm. Genes Dev 2001; 15: 1998-2009. [CrossRef]

23. Bort R, Martinez-Barbera JP, Beddington RS, Zaret KS. Hex homeobox gene-dependent tissue positioning is required for organogenesis of the ventral pancreas. Development 2004; 131: 797-806. [CrossRef]

24. Bogue CW, Ganea GR, Sturm E, Ianucci R, Jacobs HC. Hex expression suggests a role in the development and function of organs derived from foregut endoderm. Dev Dyn 2000; 219: 84-9. [CrossRef]

25. Hunter MP, Wilson CM, Jiang X, Cong R, Vasavada H, Kaestner KH, et al. The homeobox gene Hhex is essential for proper hepatoblast differentiation and bile duct morphogenesis. Dev Biol 2007; 308: 355-67. [CrossRef]

26. Clotman F, Lemaigre F. P. Control of hepatic differentiation by activin/ TGFbeta signaling. Cell Cycle 2006; 5: 168-71. [CrossRef]

27. Weinstein M, Monga SP, Liu Y, Brodie SG, Tang Y, Li C, et al. Smad proteins and hepatocyte growth factor control parallel regulatory pathways that converge on beta1-integrin to promote normal liver development. Mol Cell Biol 2001; 21: 5122-31. [CrossRef]

28. Hussain S.Z, Sneddon T, Tan X, Micsenyi A, Michalopoulos GK, Monga SP. Wnt impacts growth and differentiation in ex vivo liver development. Exp Cell Res 2004; 292: 157-69. [CrossRef]
29. Clotman F, Jacquemin P, Plumb-Rudewiez N, Pierreux CE, Van der Smissen P, Dietz HC, et al. Control of liver cell fate decision by a gradient of TGF beta signaling modulated by Onecut transcription factors. Genes Dev 2005; 19: 1849-54. [CrossRef]

30. Ouondamatte F, Knittel T, Mehde M, Ramadori G, Herken R. Matrix metalloproteinases in early human liver development Histochem Cell Biol 1999; 112: 277. [CrossRef]

31. Petorak İ. Medikal Embriyoloji. İstanbul: Beta Basım Yayım Dağıtım; 1984.

32. Enzan H, Hara H, Yamashita Y, Ohkita T, Yamane T. Fine structure of hepatic sinusoids and their development in human embryos and fetuses. Acta Pathol Jpn 1983; 33: 447-66. [CrossRef]

33. Cope EM, Dilly SA. Kupffer cell numbers during human development. Clin Exp Immunol 1990; 81: 485-88. [CrossRef]

34. Jørgensen MC, Ahnfelt-Rønne J, Hald J, Madsen OD, Seru P, Hecksher-Sørensen J. An illustrated review of early pancreas development in the mouse. Endocr Rev 2007; 28: 685-705 [CrossRef]

35. Kim SK, Hebrok M, Melton DA. Notochord to endoderm signaling is required for pancreas development. Development 1997; 124: 4243-52.

36. Hebrok M, Kim SK, Melton DA. Notochord repression of endodermal Sonic hedgehog permits pancreas development. Genes Dev 1998; 12: 1705-13. [CrossRef]

37. Lammert $\mathrm{E}$, Cleaver $\mathrm{O}$, Melton $\mathrm{D}$. Induction of pancreatic differentiation by signals from blood vessels. Science 2001; 294: 564-67. [CrossRef]

38. Cleaver O, Dor Y. Vascular instruction of pancreas development. Development 2012; 139: 2833-43. [CrossRef]

39. Jennings RE, Berry AA, Kirkwood-Wilson R, Roberts NA, Hearn T, Salisbury RJ, et al. Development of the Human Pancreas From Foregut to Endocrine Commitment. Diabetes 2013; 62: 3514-22. [CrossRef]

40. Adda G, Hannoun L, Loygue J. Development of the human pancreas: variations and pathology. A tentative classification. Anat Clin 1984; 5: 275-83. [CrossRef]

41. Gittes, GK. Developmental biology of the pancreas: A comprehensive review. Developmental Biology 2009; 326: 4-35. [CrossRef]

42. Pan FC, Wright C. Pancreas organogenesis: from bud to plexus to gland. Dev Dyn 2011; 240: 530-65. [CrossRef]

43. Habener JF, Kemp DM, Thomas MK. Minireview: transcriptional regulation in pancreatic development. Endocrinology 2005; 146: 102534. [CrossRef]

44. Kim SK, MacDonald RJ. Signaling and transcriptional control of pancreatic organogenesis. Curr Opin Genet Dev 2002; 12: 540-7. [CrossRef]

45. Parkin CA, Ingham PW. The adventures of Sonic Hedgehog in development and repair. I. Hedgehog signaling in gastrointestinal development and disease. Am J Physiol Gastrointest Liver Physiol 2008; 294: 363-7. [CrossRef]

46. Kim W, Shin YK, Kim BJ, Egan JM. Notch signaling in pancreatic endocrine cell and diabetes. Biochem Biophys Res Commun 2010; 392: 247-51. [CrossRef]

47. Bruce CM. Human embryology and developmental biology. St. Louis: Mosby; 2004.

48. Edlund, H. Developmental biology of the pancreas. Diabetes 2001; 50: 5-9. [CrossRef]

49. Cleveland MH, Sawyer JM, Afelik S, Jensen J, Leach SD. Exocrine ontogenies: on the development of pancreatic acinar, ductal and centroacinar cells. Semin Cell Dev Biol 2012; 23: 711-9. [CrossRef]

50. Zhou Q, Law AC, Rajagopal J, Anderson WJ, Gray PA, Melton DA. A multipotent progenitor domain guides pancreatic organogenesis. Dev Cell 2007; 13: 103-14. [CrossRef]

51. Ketola I, Otonkoski T, Pulkkinen MA, et al. Transcription factor GATA- 6 is expressed in the endocrine and GATA- 4 in the exocrine pancreas. Mol Cell Endocrinol 2004; 226: 51-7. [CrossRef]

52. Jeon J, Correa-Medina M, Ricordi C, Edlund H, Diez JA. Endocrine cell clustering during human pancreas development. J Histochem Cytochem 2009; 57: 811-24. [CrossRef] 